\title{
Adsorption of Lead (II) and Copper (II) Ions from Mono Synthetic Aqueous Solutions Using Bio-Char from Ficus natalensis Fruits
}

\author{
Godfrey Musumba ${ }^{1,2}$, Caroline Nakiguli1 ${ }^{1}$, Cranmer Lubanga ${ }^{3}$, Paul Mukasa ${ }^{1}$, Emmanuel Ntambi $^{*}$ \\ ${ }^{1}$ Department of Chemistry, Mbarara University of Science and Technology, Mbarara, Uganda \\ ${ }^{2}$ St. Joseph's Secondary School, Butenga, Masaka, Uganda \\ ${ }^{3}$ Department of Science, Bugema University, Luweero, Uganda \\ Email: ^emmantambi@must.ac.ug
}

How to cite this paper: Musumba, G., Nakiguli, C., Lubanga, C., Mukasa, P. and Ntambi, E. (2020) Adsorption of Lead (II) and Copper (II) Ions from Mono Synthetic Aqueous Solutions Using Bio-Char from Ficus natalensis Fruits. Journal of Encapsulation and Adsorption Sciences, 10, 71-84. https://doi.org/10.4236/jeas.2020.104004

Received: September 3, 2020

Accepted: November 23, 2020

Published: November 27, 2020

Copyright $\odot 2020$ by author(s) and Scientific Research Publishing Inc. This work is licensed under the Creative Commons Attribution International License (CC BY 4.0).

http://creativecommons.org/licenses/by/4.0/

\begin{abstract}
Many science-based institutions in most developing countries use heavy metal containing salts in practical teaching sessions. The commonly used chemicals are the salts of lead (II) and copper (II) and the wastes generated end up into the environment when untreated. Thus, a study was done to remove lead (II) and copper (II) ions from mono synthetic aqueous solution using bio-char from Ficus natalensis fruits (FNF). This was done at varied $\mathrm{pH}$, contact time, temperature, bio-char dosage level, salinity and metal ion concentration using the batch approach. The residual metal concentrations were determined using the atomic absorption spectrophotometer. The optimum $\mathrm{pH}$ for the adsorption of copper (II) and lead (II) ions was found to be 4.0 and 5.0 respectively. The maximum percentage adsorption of copper (II) and lead (II) by the FNF bio-char was established at 60 minutes contact time, $47.5^{\circ} \mathrm{C}$ and $0.4 \mathrm{~g}$ adsorbent dose. Increase in the metal ion concentration and the presence of interfering ions in the aqueous solution lead to decrease in the percentage adsorption. The highest adsorption capacity was found to be $161.29 \mathrm{mg} / \mathrm{g}$ and $1250 \mathrm{mg} / \mathrm{g}$ for copper (II) and lead (II) ions respectively. The thermodynamic parameters indicated the feasibility of the adsorption of copper (II) and lead (II) on the bio-char of FNF. Thus, bio-char from FNF may be used as an adsorbent in waste management where copper (II) and lead (II) ions are present at a concentration range of between 5 and $100 \mathrm{mg} / \mathrm{l}$.
\end{abstract}

\section{Keywords}

Bio-Char, Ficus natalensis Fruits, Heavy Metal, Wastewater

\section{Introduction}

Heavy metal pollution is a serious problem globally owing to their toxicity and 
non-biodegradability [1]. Heavy metals such as mercury, cadmium, chromium, zinc, copper, and lead are toxic and poisonous at high concentrations [2]. For instance, in children below six years of age if exposed to as low as $5 \mu \mathrm{g} / \mathrm{dl}$ of lead, they suffer from reduction in intelligence quotient (IQ), disabilities in learning, stunted growth, impaired hearing, behavioural problems, disorders inattention and kidney damage [3]. High amounts of lead in children may result into mental retardation, coma, or even death [4]. In adults, lead increases blood pressure, fertility problems, nerve disorders, muscle and joint pain, irritability, memory impairments [5]. Accumulation of copper in the body at levels above $1.0 \mathrm{~g}$ causes gastrointestinal mucosal ulcerations and central-nervous system (CNS) manifestations including headache, dizziness and convulsions [4].

Mainly aqueous solution mixtures containing heavy metals are used during practical teaching in school laboratories with poor means of effluent disposal especially in developing countries. The effluents containing heavy metal ions like lead (II) and copper (II) are in most cases discharged into the environment, and then taken up by plants, animals, and humans. This is because, the conventional methods for removal of such heavy metals from effluents are sometimes not affordable, due to the costs involved, as well as being inefficient to remove low metal ion concentrations particularly in the range of $1-100 \mathrm{mg} / \mathrm{l}$ [3].

Of recent, the capacity of plant materials in adsorbing heavy metal ions has been widely used to develop new technologies which are cheap, efficient and environmental friendly for laboratory effluent treatment especially when the metal ion concentration is as low as $1 \mathrm{mg} / \mathrm{l}$ [4] [6]. Biomass materials and plant wastes have been successfully used for metal ion bio-sorption and this technology needs to be developed further for sustainable use in pollution abatement programme [7].

This study, therefore, investigated the removal of lead (II) and copper (II) ions from standard mono synthetic aqueous solutions at different conditions using bio-char from Ficus natalensis fruits (FNF).

\section{Materials and Methods}

\subsection{Collection and Preparation of Adsorbent}

Fresh FNF were collected by hand picking from Bwanda village, Kalungu District, Uganda. The fruits were dried under the laboratory shade at room temperature. The dried fruits were pulverised using a porcelain pestle and mortar and sieved using a plastic sieve of particle size $710 \mu \mathrm{m}$ [8]. Natalensis fruit FNF bio-char was prepared by burning the fruits powder on a Kjeldahl apparatus at $150^{\circ} \mathrm{C}$ for four hours [8]. The black material formed was the bio-char, which was kept in clean and transparent polyethylene sample bags for further use.

\subsection{Preparation of Standard Mono-Synthetic Aqueous Stock Solutions}

Aqueous stock solution of copper (II) ions was prepared by dissolving $2.79 \mathrm{~g}$ of 
analytical grade pentahydrate copper (II) sulphate $\left(\mathrm{CuSO}_{4} \cdot 5 \mathrm{H}_{2} \mathrm{O}\right)$ in one litre of double distilled water. In the same way, the aqueous stock solution of lead (II) ions was prepared by dissolving $3.69 \mathrm{~g}$ of lead (II) nitrate $\left(\mathrm{Pb}\left(\mathrm{NO}_{3}\right)_{2}\right)$ in one litre of double distilled water. The stock solutions were each diluted to make solutions of 5, 10, 20, 40, 50, 60, 80, $100 \mathrm{mg} / \mathrm{l}[9]$.

\subsection{Batch Adsorption Experiments}

The experiments were carried out at varying conditions ( $\mathrm{pH}$, contact time, temperature, adsorbent dose, metal ion concentration and salinity) to assess the performance of bio-char from FNF in removing lead (II) and copper (II) ions from standard mono synthetic aqueous solutions. Experiments done were in triplicates and the average amounts of metal ions adsorbed were obtained and used accordingly [10].

The effect of varying $\mathrm{pH}(1,2,3,4,5,6,7$, and 8$)$ values on removing copper (II) ions $(50 \mathrm{mg} / \mathrm{l}, 100 \mathrm{ml})$ was determined using the bio-char $0.2 \mathrm{~g}$ in a $250 \mathrm{ml}$ conical flask at $25^{\circ} \mathrm{C}$. Each mixture made was shaken at $100 \mathrm{rpm}$ using an end-over-end shaker for one hour, filtered through Whatman filter paper (No. 42) and the concentration of copper (II) ions remaining were determined using atomic adsorption spectrophotometer (AAS). Adsorption percentage at equilibrium, $A_{e q}$ was calculated using Equation (1).

$$
A_{e q}(\%)=\left(\frac{C_{o}-C_{e}}{C_{o}}\right) * 100
$$

where $C_{o}$ and $C_{e}$ is the initial and equilibrium metal concentrations $(\mathrm{mg} / \mathrm{l})$ in the standard aqueous solution respectively [10]. The $\mathrm{pH}$ was adjusted using $0.1 \mathrm{M}$ sodium hydroxide or $0.1 \mathrm{M}$ sulphuric acid. The procedure was repeated for adsorption of lead (II) ions from the standard aqueous solutions prepared.

The other factors studied were varied as follows; contact time $(1,10,20,30$, 40, 50, 60 and 70) minutes at an optimum $\mathrm{pH}$ of 5 obtained from this study; temperature $\left(25^{\circ} \mathrm{C}, 30^{\circ} \mathrm{C}, 35^{\circ} \mathrm{C}, 40^{\circ} \mathrm{C}, 45^{\circ} \mathrm{C}, 50^{\circ} \mathrm{C}, 55^{\circ} \mathrm{C}\right.$ and $\left.60^{\circ} \mathrm{C}\right)$ at pH 5 for one hour; adsorbent dose $(0.1,0.2,0.3,0.4,0.5$ and 0.6$) \mathrm{g}$ at $25^{\circ} \mathrm{C}$, $\mathrm{pH} 5$ for one hour; salinity $(5,10,15,20,25$ and 30$) \mathrm{g} / \mathrm{l}$ of potassium chloride or sodium chloride at $25^{\circ} \mathrm{C}, \mathrm{pH} 5$ for one hour. The initial metal ion concentration of copper (II) and lead (II) was varied as (5, 10, 20, 40, 50, 60, 80 and 100) $\mathrm{mg} / \mathrm{l}$ each in 100 $\mathrm{ml}$, at $25^{\circ} \mathrm{C}, \mathrm{pH} 5$ for one hour. Then in addition to $A_{e q}$ adsorption capacity, $Q_{e}$ was determined using Equation (2).

$$
Q_{e}(\mathrm{mg} / \mathrm{g})=\frac{V\left(C_{o}-C_{e}\right)}{W}
$$

where $C_{o}$ and $C_{e}$ is the initial and final metal concentration $(\mathrm{mg} / \mathrm{l})$ in solution respectively, $V$ is the volume $(\mathrm{ml})$ of the solution, $W$ is the mass $(\mathrm{g})$ of the bio-char used. For the school effluents collected from secondary schools in Uganda, $\mathrm{pH}$ was adjusted to $\mathrm{pH} 5$ and adsorbent dosage level was set at $0.4 \mathrm{~g}$ for 60 minutes at $45^{\circ} \mathrm{C}$. 


\section{Results and Discussion}

\subsection{Effect of $\mathrm{pH}$}

Adsorption of lead (II) and copper (II) ions was found to be highly dependent on pH (Figure 1). The optimal pH was 5 and 4 for copper (II) and lead (II) ions respectively. This means that the adsorption of copper (II) and lead (II) ions mostly occurs at an acidic $\mathrm{pH}$. The low adsorption at low $\mathrm{pH}$ was as a result of hydroxonium ions $\left(\mathrm{H}_{3} \mathrm{O}^{+}\right)$domination that competed with the metal ions for the active binding/active sites on the bio-char as described by the chemical Equation (3).

$$
\mathrm{M}^{2+}+2 \mathrm{H}_{2} \mathrm{O} \rightarrow \mathrm{M}(\mathrm{OH})^{+}+\mathrm{H}_{3} \mathrm{O}^{+}
$$

The overall bio-char surface becomes positive and so, the metal ions suffer from strong repulsive forces [11]. It should further be noted that $\mathrm{pH}$ affects the solubility of the metal ions due to the counter ion concentration on the functional groups of the adsorbent and the degree of ionization of the adsorbate during the reaction [12].

As $\mathrm{pH}$ increases, percentage adsorption also increased because of reduction in the competition from hydroxonium ions due to the formation of $\mathrm{M}(\mathrm{OH})_{3}^{-}$ complex as described by chemical Equation (4), and the complex formed readily binds with the positively charged active sites of the bio-char [13]

$$
\mathrm{M}^{2+}+3 \mathrm{H}_{2} \mathrm{O} \rightarrow \mathrm{M}(\mathrm{OH})_{3}^{-}+3 \mathrm{H}^{+}
$$

The increased negative charge density on bio-char surface increases the attraction of the positively charged ions resulting in the increasing percentage removal of the metal ions [14]. Above the optimum $\mathrm{pH}$ greater than 6, probably precipitation of the metal ion by hydroxides took place, which led to low removal of the metal ions by the bio-char [12] [15] as described by chemical Equation (5).

$$
\mathrm{M}^{2+}+2 \mathrm{OH}^{-} \rightarrow \mathrm{M}(\mathrm{OH})_{2}
$$

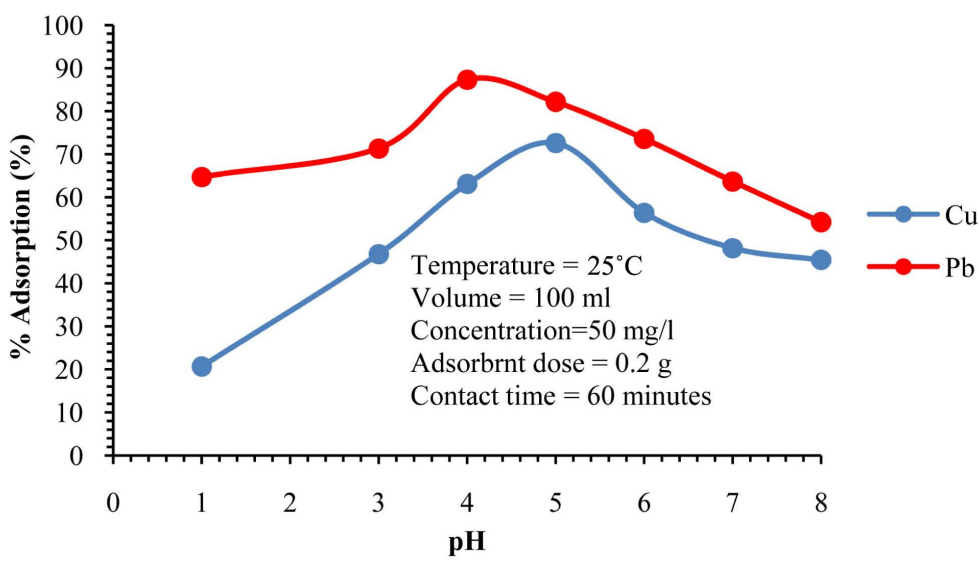

Figure 1. Effect of $\mathrm{pH}$ on adsorption of copper (II) and lead (II) ions using FNF bio-char. 
Results obtained in this study are in agreement with [7] [15] [16] where they reported increase in adsorption as $\mathrm{pH}$ increased and decreased after the optimum $\mathrm{pH}$.

\subsection{Effect of Contact Time}

Increased adsorption in both cases, Figure 2 was due to the availability of many vacant sites, which provided a large surface area for more ions to get adsorbed onto the bio-char active sites [17] [18] [19].

However, the adsorption of copper (II) was lower owing to the fact that hydroxonium ion is more attracted towards the active site than the copper ion, unlike the lead ions with a high charge density [20]. Beyond 60 minutes, there was no further increase in the adsorption due to equilibrium set by the already adsorbed and metal ions still in solution [21]. The results obtained in this study are in agreement with those obtained by [22]. The higher the charge density, the slower the rate of movement of ions towards the central bio-char sites and hence less ability to get adsorbed onto the active sites [20] [23].

\subsection{Effect of Temperature}

At temperatures of up to $30^{\circ} \mathrm{C}$ and $40^{\circ} \mathrm{C}$ (Figure 3), there is a low linear increase in percentage removal of both ions. This may be due to low kinetic energy possessed by ions, hence few ions reach the bio-char active sites [21].

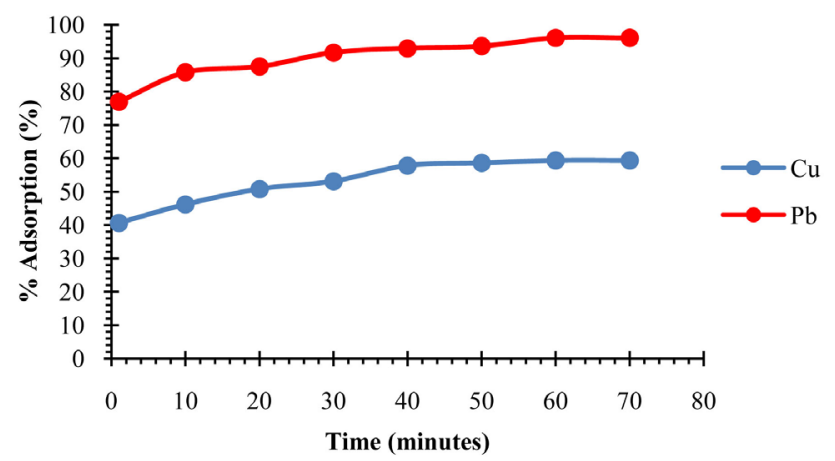

Figure 2. Effect of contact time on the adsorption of copper (II) and lead (II) ions using FNF bio-char.

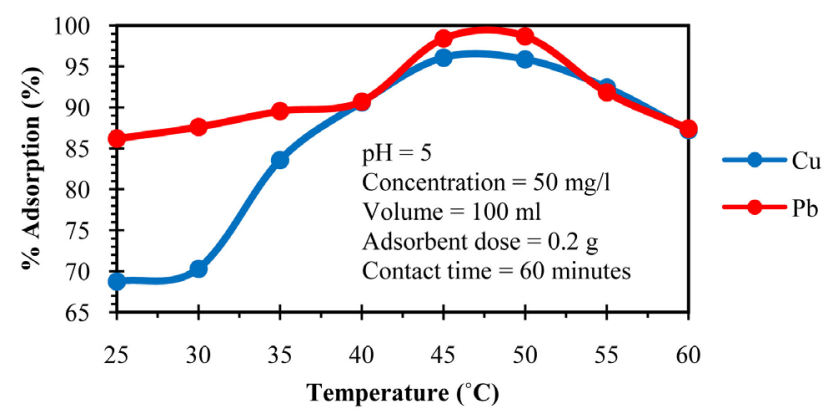

Figure 3. Effect of temperature on adsorption of copper (II) and lead (II) ions using FNF bio-char. 
At optimal temperature, the adsorption was attributed to the increased diffusion rate of ions onto the bio-char sites since diffusion is an endothermic process [2] [24]. Beyond $47.5^{\circ} \mathrm{C}$, the adsorption of both metal ions from aqueous solution reduced due to desorption of the adsorbed species [8] [25] [26].

\subsection{Effect of Adsorbent Dose}

The increase in adsorption of both metals with bio-sorbent amounts, Figure 4 is due to the increasing surface area on the bio-char [27], creating a higher availability of the binding sites that complexed the individual metal ions [3] [28].

The adsorption of lead (II) and copper (II) ions remained almost constant after the adsorbent dose of $0.4 \mathrm{~g}$ due to the reduction in the intercellular distance of the bio-char sites caused by the complexed ion species leading to shielding of binding sites from the unbounded metal ions [3]. Chaouch et al., [29] reported that the difference in adsorption of metal ions is related to their susceptibility to hydration. The hydrated ionic radius of lead (II) (4.01 $\AA$ ) is less than that of copper (II) ions (4.19 ̊). Since it is difficult for hydrated ions with larger volume to approach the center of the bio-sorption sites, copper (II) ions with high hydrated ionic radius was less adsorbed to the active sites of FNF bio-char than lead (II) ions with a less hydrated ionic radius.

\subsection{Effect of Metal Ion Concentration}

Initially, the high percentage removal of both ions from aqueous solution as given in Figure 5 is caused by the high ratio of bio-char surface sites to metal ions in the solution [30]. The general decrease in the removal of metal ions with increasing metal ion concentration is due to the reduction in the available bio-char surface active sites to metal ions [31]. At higher metal ion concentrations, the high collisions of ions and high diffusion rate, brings about low percentage removal, which also causes the saturation at the bio-char surface sites [5] [32]. The bio-char has a higher affinity for lead (II) ion than copper (II) ion because of competition for the active sites with hydronium ion, and hence a less

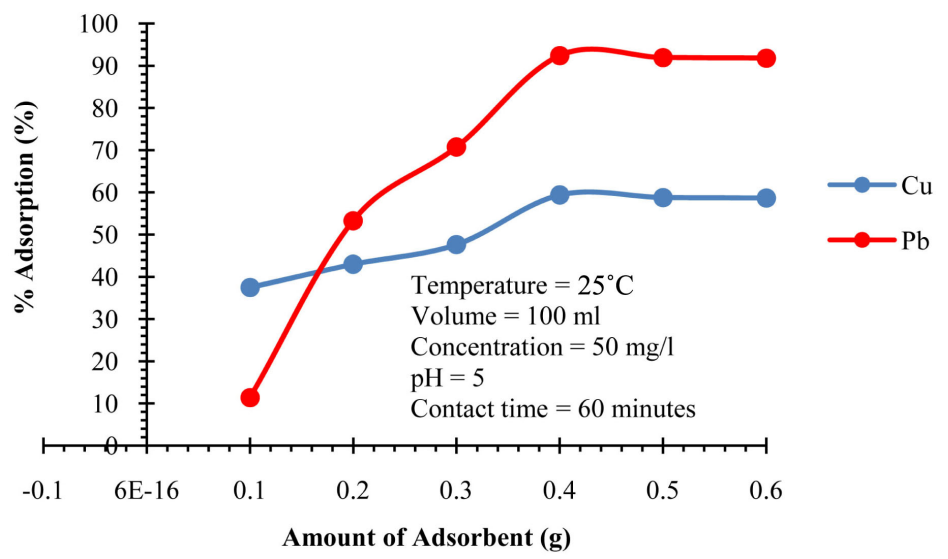

Figure 4. Effect of amount of bio-char on adsorption of copper (II) and lead (II) ions using FNF bio-char. 


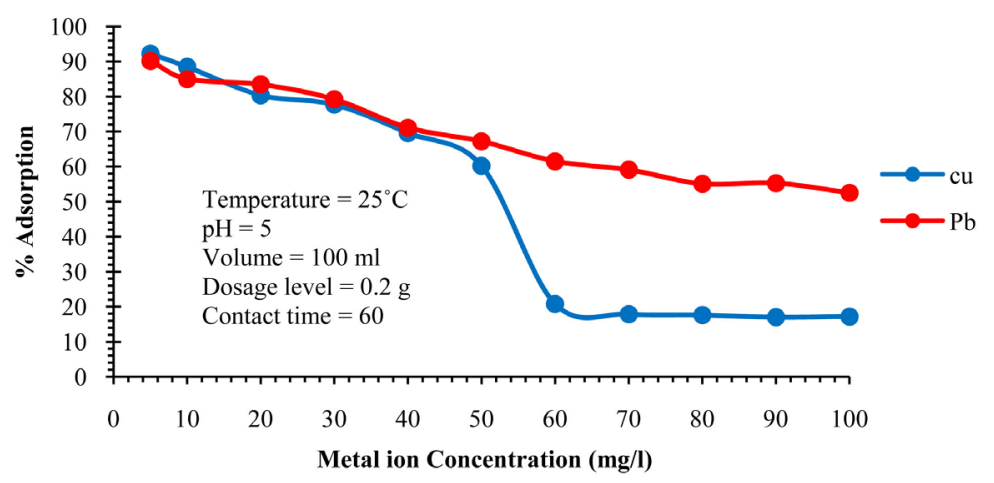

Figure 5. Effect of ion concentration on adsorption of copper (II) and lead (II) ions using FNF bio-char.

binding ability towards the bio-sorbent. The higher the relative electronegativity value, the higher the adsorption. Adsorption also increases with increasing $\mathrm{pKa}$ value of the metal, thus copper with a higher $\mathrm{pKa}(8.0)$ is adsorbed better than lead (pKa, 6.3) [33]. A similar trend of results, that is, decreasing adsorption percentage as the concentration of metal ions increases have been reported [34].

\subsection{Effect of Interfering Ions (Salinity)}

As per Figure 6, the efficiency of the adsorption process of both ions was lowered by the presence of the sodium or potassium ions in the solution matrix. Lead (II) was more adsorbed than copper (II) ions in the presence of the sodium and potassium ions. This may be brought by the different affinities of the ions for the active sites on the FNF bio-char.

Varank et al. [20] have reported that charge density plays an important role in their competitive abilities by regulating ions' accessibility to the pores of the sorbents. The smaller the charge density is, the greater the ability of the ions to be adsorbed. Potassium ions showed a higher tendency of competition for the active site than sodium ions. This may be as a result of the difference between the hydrated ionic radii of potassium and sodium ions, that is, the smaller the ionic radius of the cation, the greater the influence towards competition on the binding sites, hence potassium ions ( $2.32 \AA$ ) being more influential than sodium $(2.76 \AA)$. The results are in agreement with the work of [20] where the adsorption decreases with increasing concentration of interfering ions.

\subsection{Adsorption Isotherms}

The Langmuir and Freundlich adsorption isotherms were used to describe the behavior of copper (II) and lead (II) ions onto the bio-char surface due to their commonality in use. The Langmuir takes an assumption that the sorption occurs at specific homogeneous sites within the bio-char [35]. The data was checked using the Langmuir isotherm equation: $\frac{C_{e}}{q_{e}}=\frac{1}{K_{L} q_{o}}+\frac{C_{e}}{q_{o}}$ by plotting a graph of $\left(\frac{c_{e}}{q_{e}}\right)$ against $\left(c_{e}\right)$ where $K_{L}$ and $q_{o}$ are Langmuir constants related to rate of 


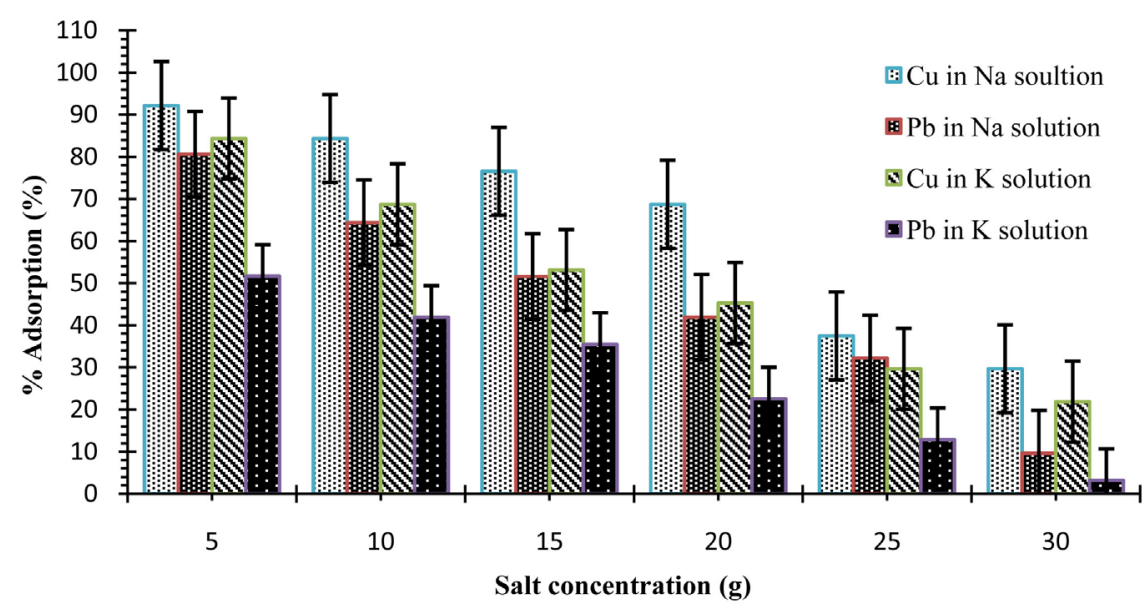

Figure 6. Effect of interfering ions on the adsorption of copper (II) and lead (II) ions using FNF bio-char.

adsorption and adsorption capacity respectively, and $\frac{1}{q_{o}}$ is the slope. The data fitted well in the Langmuir isotherm model for lead (II) ions as shown in Figure 7 with regression coefficient $\left(r^{2}\right)$ of 0.9732 . The results for copper (II) less fitted the model with $r^{2}$ of 0.6479 (Table 1). The linearity of the plot (Figure 7) indicates the validity of the Langmuir equation that supports monolayer formation on the surface of bio-char.

The separation factor $\left(R_{L}\right)$ is the dimensionless form of the Langmuir isotherm given by $R_{L}=\left(\frac{1}{1+K_{l} C_{o}}\right)$, and it is observed that the separation factor $R_{L}$ is 0.167 for lead (II) and 0.035 for copper (II) ions which justifies that the adsorption process was favorable $\left(0<R_{L}<1\right)$ [36].

To check heterogeneity adsorption, data was fitted on the Freundlich equation; $\log q_{e}=\log K_{f}+\frac{1}{n} \log C_{e}$. A plot of $\log q_{e}$ against $\log C_{e}$ yielded a straight line. From the slope, $n$ was 1.922 and 3.604 for lead (II) and copper (II) ions indicate a physical adsorption process. The Freundlich adsorption isotherms for copper (II) and lead (II) ions are presented in Figure 8 and the parameters obtained are given in Table 1. It can therefore be concluded that the adsorption of lead (II) was better for both Langmuir and Freundlich adsorption isotherms than for copper (II) ions. A comparison was made of FNF biochar against other adsorbents that have been used to remove copper (II) and lead (II) ions from aqueous solution. It can be observed that FNF biochar compare well with the other adsorbents listed in Table 2.

\subsection{Thermodynamics of Adsorption}

The equilibrium constant $\left(K_{c}\right)$, standard Gibbs free energy change $\left(\Delta G^{\circ}\right)$, entropy change $\left(\Delta S^{\circ}\right)$ and enthalpy change $\left(\Delta H^{\circ}\right)$ of adsorption were calculated using Equations (6), (7) and (8). 


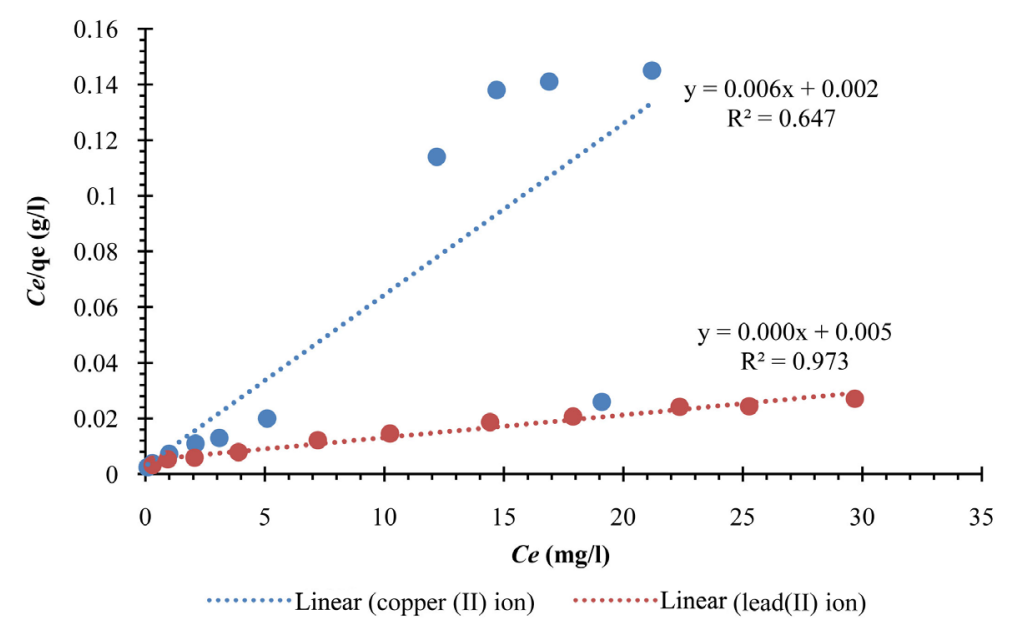

Figure 7. Langmuir adsorption isotherm for the adsorption of lead (II) and copper (II) ions.

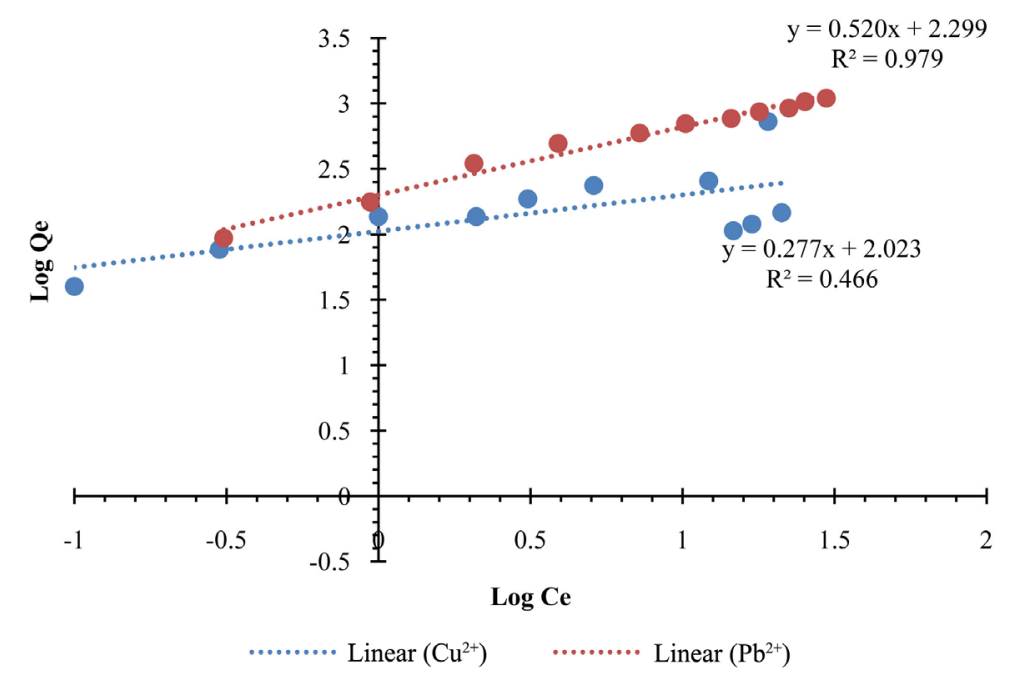

Figure 8. Freundlich adsorption isotherm for the adsorption of lead (II) and copper (II) ions.

Table 1. Langmuir and Freundlich adsorption isotherm parameters for the adsorption of copper (II) and lead (II) ions from aqueous solution using FNF bio-char.

\begin{tabular}{cccccccc}
\hline \multirow{2}{*}{ Metal ion } & \multicolumn{4}{c}{ Langmuir isotherm } & \multicolumn{4}{c}{ Freundlich isotherm } \\
\cline { 2 - 8 } & $r^{2}$ & $q_{m}(\mathrm{mg} / \mathrm{g})$ & $K_{l}(\mathrm{~L} / \mathrm{Fmg})$ & $R_{L}$ & $\mathrm{r}^{2}$ & $n$ & $K_{f}(\mathrm{mg} / \mathrm{g})$ \\
\hline $\mathrm{Pb}^{2+}$ & 0.9732 & 1250 & 0.16 & 0.167 & 0.9799 & 1.922 & 199.43 \\
$\mathrm{Cu}^{2+}$ & 0.6479 & 161.29 & 0.188 & 0.035 & 0.4668 & 3.604 & 105.58 \\
\hline
\end{tabular}

$q_{m}$ is the maximum adsorption capacity, $K_{l}$ is the binding affinity which gives the extent of adsorption, $n$ is the adsorption intensity and $K_{f}$ is the binding capacity.

$$
K_{c}=\frac{C_{o}}{C_{e}}
$$

where $K_{c}$ is the equilibrium constant, $C_{o}$ is the concentration of metal ions adsorbed $(\mathrm{mg} / \mathrm{g})$ on the biosorbent at a given temperature and $c_{e}$ is the initial 
Table 2. Comparison of the current work with other researchers.

\begin{tabular}{ccc}
\hline Material & $\boldsymbol{q}_{m}(\mathrm{mg} / \mathrm{g})$ & Source \\
\hline CuO nanostructures & $125\left(\mathrm{~Pb}^{2+}\right)$ & {$[36]$} \\
Rice husk & $133.34\left(\mathrm{Cu}^{2+}\right)$ & {$[27]$} \\
Rice husk & $45.5\left(\mathrm{~Pb}^{2+}\right)$ & {$[15]$} \\
Prosopis juliflora & $201.08\left(\mathrm{Cu}^{2+}\right)$ & {$[20]$} \\
Cymbopogon citrusstem & $1000\left(\mathrm{~Pb}^{2+}\right)$ & {$[37]$} \\
Wasted black tea & $166.67\left(\mathrm{Cu}^{2+}\right)$ & {$[38]$} \\
F. natalensis fruits biochar & $1250\left(\mathrm{~Pb}^{2+}\right)$ & Current study \\
\hline
\end{tabular}

metal ion concentration $(\mathrm{mg} / \mathrm{l})$. The $K_{c}$ values were used to determine the standard Gibb's free energy change, $\Delta G^{\circ}$, enthalpy change, $\Delta H^{\circ}$ and entropy change, $\Delta S^{\circ}$ for adsorption of copper (II) and lead (II) ions on bio-char of FNF as given by Equations (7) and (8).

$$
\Delta G^{\circ}=-R T \ln K_{c}
$$

where $\Delta G^{\circ}$ the free energy change of adsorption, $T$ is the absolute temperature in Kelvin, $R$ is the universal gas constant. The $K_{c}$ may be expressed in terms of the $\Delta G^{\circ}$ and $\Delta S^{\circ}$ as a function of temperature as given by the Van't Hoff's reaction isotherm in Equation (8).

$$
\ln K_{c}=\left(\frac{-\Delta H^{\circ}}{R}\right)\left(\frac{1}{T}\right)+\left(\frac{\Delta S^{\circ}}{R}\right)
$$

From Figure 9 the results of $\Delta G^{\circ}, \Delta H^{\circ}$ and $\Delta S^{\circ}$ are as presented in Table 3. The negative values of $\Delta G^{\circ}$ indicate the feasibility of the adsorption process, though less feasible with temperature.

The positive values of $\Delta H^{\circ}$ and $\Delta S^{\circ}$ indicate that the adsorption process of copper (II) and lead (II) ions on FNF bio-char was endothermic and favorable respectively [36]. This particular adsorption is therefore a multimolecular layer and reversible with the bonds majorly weak van der Waal's.

\subsection{Adsorption of Copper (II) and Lead (II) Ions from School Laboratory Effluents}

In this study, laboratory effluents were collected from three secondary schools and analysed to determine the amount of lead (II) and copper (II) ions present and subsequently removed. The results obtained are as given in Table 4 . The values obtained gave the basis for selecting concentration range that could be available for the use of FNF bio-char and provide evidence that the bio-char can be used to treat effluents. All the effluents were adjusted to the $\mathrm{pH}$ of 5 , adsorbent dosage level set at $0.4 \mathrm{~g}$ for 60 minutes at $47.5^{\circ} \mathrm{C}$.

The low percentage adsorption could be attributed to ion interferences in which several other salts and acids containing chlorides, nitrates, sulphates, 


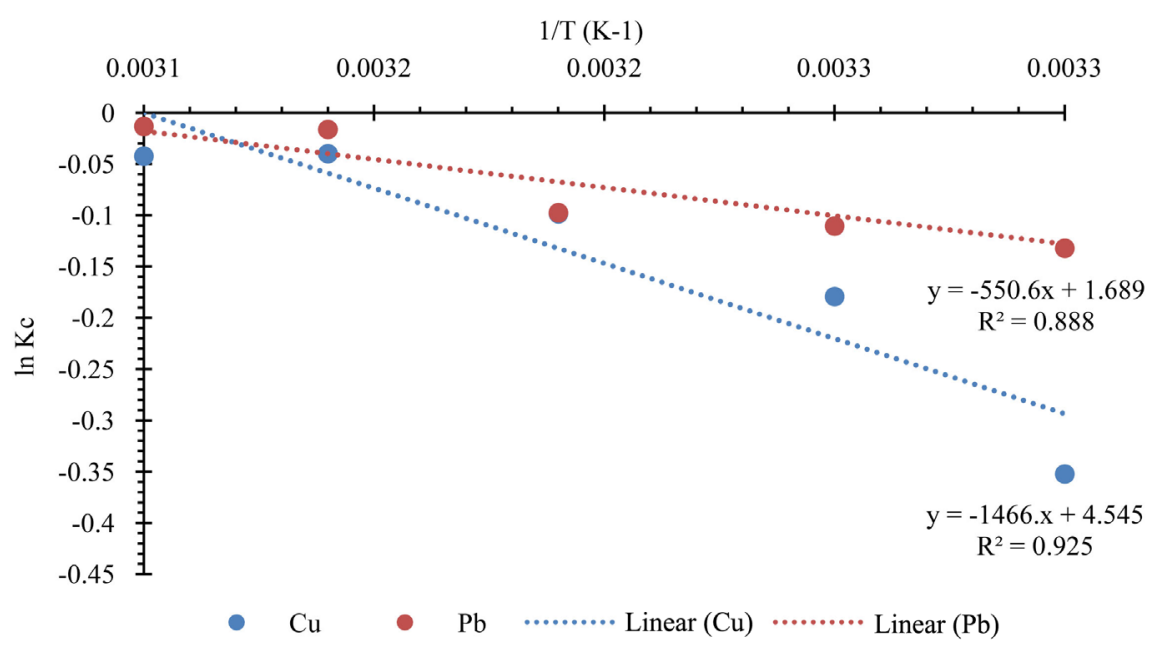

Figure 9. A graph of $\ln K_{c}$ against $1 / T$.

Table 3. Thermodynamic parameters for the adsorption of copper (II) and lead (II) ions.

\begin{tabular}{|c|c|c|c|c|c|c|}
\hline \multirow{2}{*}{$\begin{array}{l}\text { Temperature } \\
\text { (K) }\end{array}$} & \multicolumn{2}{|c|}{$\Delta G^{\circ} \mathrm{J} \cdot \mathrm{mol}^{-1}$} & \multicolumn{2}{|c|}{$\Delta H^{\circ} \mathrm{J} \cdot \mathrm{mol}^{-1}$} & \multicolumn{2}{|c|}{$\Delta S^{\mathrm{o}} \mathrm{J}^{1} \cdot \mathrm{K}^{-1} \cdot \mathrm{mol}^{-1}$} \\
\hline & $\mathrm{Cu}$ & $\mathrm{Pb}$ & $\mathrm{Cu}$ & $\mathrm{Pb}$ & $\mathrm{Cu}$ & $\mathrm{Pb}$ \\
\hline 298 & -928.330 & -369.158 & & & \multirow{6}{*}{+37.794} & \multirow{6}{*}{+14.042} \\
\hline 303 & -887.294 & -332.527 & & & & \\
\hline 308 & -458.883 & -281.678 & $+12,192.481$ & +4577.688 & & \\
\hline 313 & -256.169 & -252.421 & $(2.914 \mathrm{kcal} / \mathrm{mol})$ & $(1.094 \mathrm{kcal} / \mathrm{mol})$ & & \\
\hline 318 & -105.347 & -42.302 & & & & \\
\hline 323 & -85.259 & -34.910 & & & & \\
\hline
\end{tabular}

Table 4. Adsorption of copper (II) and lead (II) ions from school laboratory wastes.

\begin{tabular}{ccccc}
\hline & Metal $(\mathrm{mg} / \mathrm{l})$ & \multicolumn{3}{c}{ School } \\
\cline { 3 - 5 } & & $\mathrm{A}$ & $\mathrm{B}$ & $\mathrm{C}$ \\
\hline $\begin{array}{c}\text { Concentration } \\
\text { present }\end{array}$ & $\mathrm{Cu}$ & $49.88 \pm 0.67$ & $60.46 \pm 3.14$ & $32.48 \pm 1.44$ \\
& $\mathrm{~Pb}$ & $27.72 \pm 1.37$ & $68.56 \pm 0.70$ & $52.62 \pm 2.08$ \\
$\%$ adsorption & $\mathrm{Cu}$ & 45.80 & 15.80 & 68.98 \\
& $\mathrm{~Pb}$ & 62.18 & 59.06 & 85.45 \\
\hline
\end{tabular}

A: St. Theresa Girls' Secondary School, Bwanda, Kalungu District; B: St. Joseph's Secondary \& Technical School Kiteredde, Kyotera District; and C: St. Joseph's Secondary School Butenga, Bukomansimbi District.

could have been used during laboratory sessions. Thus, wastes with copper (II) and lead (II) ions in the above range of concentrations may effectively be removed by the bio-char of FNF provided effects such as ion interference are minimized.

\section{Conclusion}

The bio-char from FNF at $47.5^{\circ} \mathrm{C}$ showed an ability to absorb copper (II) and 
lead (II) ions from aqueous solutions endothermically. The process took place efficiently at $\mathrm{pH}$ of 5 and 4 , with adsorbent dosage level of $0.4 \mathrm{~g}$ for 60 minutes. The maximum adsorption capacity was $161.29 \mathrm{mg} / \mathrm{g}$ for copper (II) and 1250 $\mathrm{mg} / \mathrm{g}$ for lead (II) ions when fitted in the Langmuir model. Bio-char from FNF may therefore be adopted as a potential material to use during treatment of waste aqueous solutions from industries and school laboratories containing heavy metals especially those of copper (II) and lead (II) ions at a concentration range of between 5 and $100 \mathrm{mg} / \mathrm{l}$.

\section{Acknowledgements}

The authors wish to acknowledge the support from Mbarara University of Science and Technology, and the assistance rendered from Department of Geology and Petroleum Studies, College of Natural Sciences, Makerere University.

\section{Conflicts of Interest}

The authors declare no conflicts of interest regarding the publication of this paper.

\section{References}

[1] Heidari, A., Younesi, H. and Mehraban, Z. (2009) Removal of Ni(II), Cd(II), and $\mathrm{Pb}$ (II) from a Ternary Aqueous Solution by Amino Functionalized Mesoporous and Nano Mesoporous Silica. Chemical Engineering Journal, 153, 70-79. https://doi.org/10.1016/j.cej.2009.06.016

[2] Singanan, M. (2011) Removal of Lead(II) and Cadmium(II) Ions from Wastewater Using Activated Biocarbon. Science Asia, 37, 115-119. https://doi.org/10.2306/scienceasia1513-1874.2011.37.115

[3] Liu, X., Hu, Q., Fang, Z., Zhang, X. and Zhang, B. (2008) Magnetic Chitosan Nanocomposites: A Useful Recyclable Tool for Heavy Metal Ion Removal. Langmuir, 25, 3-8. https://doi.org/10.1021/la802754t

[4] Aaseth, J. and Norseth, T. (1986) Handbook on the Toxicity of Metals. Elsevier, Amsterdam.

[5] Ngomsik, A.F., Bee, A., Siaugue, J.M., Talbot, D., Cabuil, V. and Cote, G. (2009) Co(II) Removal by Magnetic Alginate Beads Containing Cyanex 272 . Journal of Hazardous Materials, 166, 1043-1049. https://doi.org/10.1016/j.jhazmat.2008.11.109

[6] Mall, I.D., Srivastava, V.C. and Agarwal, N.K. (2006) Removal of Orange-G and Methyl Violet dyes by Adsorption Onto Bagasse Fly Ash-Kinetic Study and Equilibrium Isotherm Analyses. Dyes and Pigments, 69, 210-223. https://doi.org/10.1016/j.dyepig.2005.03.013

[7] Schmitz, C. (1986) The Rise of Big Business in the World Copper Industry 18701930. The Economic History Review, 39, 392-410. https://doi.org/10.2307/2596347

[8] Lubanga, C., Ntambi, E. and Adaku, C. (2017) Potential of Artocarpus Heterophyllus Seed Powder in the Adsorption of Chromium(VI) from Aqueous Solution. Journal of Water Resource and Protection, 9, 614-628. https://doi.org/10.4236/jwarp.2017.96041

[9] Alemeyahu, A., Silva A., Prasada, R.A.A. and Malairajan, S. (2008) Removal of 
$\mathrm{Pb}(\mathrm{II})$ Ions from Aqueous Solutions Using Activated Carbon from Militia Ferruginea Plant Leaves. Bulletin of the Chemical Society of Ethiopia, 22, 350-359. https://doi.org/10.4314/bcse.v22i3.61207

[10] Gibernau, M., Buser, H.R., Frey, J.E. and Hossaert-McKey, M. (1997) Volatile Compounds from Extracts of Figs of Ficuscarica. Phytochemistry, 46, 241-244. https://doi.org/10.1016/S0031-9422(97)00292-6

[11] Haghseresht, F. and Lu, G.Q. (1998) Adsorption Characteristics of Phenolic Compounds Onto Coal-Reject-Derived Adsorbents. Energy \& Fuels, 12, 1100-1107. https://doi.org/10.1021/ef9801165

[12] Shukla, S.R. and Pai, R.S. (2005) Adsorption of $\mathrm{Cu}(\mathrm{II}), \mathrm{Ni}(\mathrm{II})$ and $\mathrm{Zn}(\mathrm{II})$ on Dye Loaded Groundnut Shells and Sawdust. Separation and purification Technology, 43, 1-8. https://doi.org/10.1016/j.seppur.2004.09.003

[13] Garrels, R.M. and Thompson, M.E. (1960) Oxidation of Pyrite by Iron Sulfate Solutions. American Journal of Science, 258, 57-67.

[14] Kanu, S.A., Moyo, M., Zvinowanda, C.M. and Okonkwo, J.O. (2016) Biosorption of $\mathrm{Pb}$ (II) from Aqueous Solution Using Rooibos Shoot Powder (RSP). Desalination and Water Treatment, 57, 5614-5622. https://doi.org/10.1080/19443994.2015.1004116

[15] Liu, L., Li, C., Bao, C., Jia, Q., Xiao, P., Liu, X. and Zhang, Q. (2012) Preparation and Characterization of Chitosan/Graphene Oxide Composites for the Adsorption of $\mathrm{Au}(\mathrm{III})$ and Pd(II). Talanta, 93, 350-357. https://doi.org/10.1016/j.talanta.2012.02.051

[16] Pandey, P., Sambi, S.S., Sharma, S.K. and Singh, S. (2009) Batch Adsorption Studies for the Removal of $\mathrm{Cu}$ (II) Ions by Zeolite $\mathrm{NaX}$ from Aqueous Stream. Proceedings of the World Congress on Engineering and Computer Science, San Francisco, 22-24 October 2019, 20-22.

[17] Mousavi, H.Z., Hosseinifar, A. and Jahed, V. (2010) Removal of Cu(II) from Wastewater by Waste Tire Rubber Ash. Journal of the Serbian Chemical Society, 75, 845-853. https://doi.org/10.2298/JSC090410044M

[18] Benzaoui, T., Selatnia, A. and Djabali, D. (2018) Adsorption of Copper(II) Ions from Aqueous Solution Using Bottom Ash of Expired Drugs Incineration. Adsorption Science \& Technology, 36, 114-129. https://doi.org/10.1177/0263617416685099

[19] Prasad, T.N., Kambala, V.S.R. and Naidu, R. (2013) Phyconanotechnology: Synthesis of Silver Nanoparticles Using Brown Marine Algae Cystophora Moniliformis and their Characterisation. Journal of applied phycology, 25, 177-182. https://doi.org/10.1007/s10811-012-9851-Z

[20] Varank, G., Demir, A., Yetilmezsoy, K., Top, S., Sekman, E. and Bilgili, M.S. (2012) Removal of 4-Nitrophenol from Aqueous Solution by Natural Low-Cost Adsorbents. Indian Journal of Chemical Technology, 19, 7-25.

[21] Dar, B.A., Taher, A., Wani, A. and Farooqui, M. (2013) Isotherms and Thermodynamic Studies on Adsorption of Copper on Powder of Shed Pods of Acacia Nilotica. Journal of Environmental Chemistry and Ecotoxicology, 5, 17-20.

[22] Rahmati, A., Ghaemi, A. and Samadfam, M. (2012) Kinetic and Thermodynamic studies of Uranium(VI) Adsorption Using Amberlite IRA-910 Resin. Annals of Nuclear Energy, 39, 42-48. https://doi.org/10.1016/j.anucene.2011.09.006

[23] Liu, B. and Huang, Y. (2011) Polyethyleneimine Modified Eggshell Membrane as a Novel Biosorbent for Adsorption and Detoxification of Cr(VI) from Water. Journal of Materials Chemistry, 21, 17413-17418. https://doi.org/10.1039/c1jm12329g

[24] Devi, R., Alemayehu, E., Singh, V., Kumar, A. and Mengistie, E. (2008) Removal of 
Fluoride, Arsenic and Coliform Bacteria by Modified Homemade Filter Media from Drinking Water. Bioresource Technology, 99, 2269-2274. https://doi.org/10.1016/j.biortech.2007.05.002

[25] Ho, Y.S. (2006) Isotherms for the Sorption of Lead onto Peat: Comparison of Linear and Non-Linear Methods. Polish Journal of Environmental Studies, 15, 81-86.

[26] Horsfall Jnr, M. and Spiff, A.I. (2005) Effects of Temperature on the Sorption of $\mathrm{Pb}^{2+}$ and $\mathrm{Cd}^{2+}$ from Aqueous Solution by Caladium Bicolor (Wild Cocoyam) Biomass. Electronic Journal of Biotechnology, 8, 163-169.

[27] El-Moselhy, K.M., Abdel-Azzem, M., Amer, A. and Al-Prol, A.E. (2017) Adsorption of $\mathrm{Cu}$ (II) and Cd (II) from Aqueous Solution by Using Rice Husk Adsorbent. Physical Chemistry: An Indian Journal, 12, 109.

[28] Goel, J., Kadirvelu, K., Rajagopal, C. and Garg, V.K. (2005) Removal of Lead(II) by Adsorption Using Treated Granular Activated Carbon: Batch and Column Studies. Journal of Hazardous Materials, 125, 211-220. https://doi.org/10.1016/j.jhazmat.2005.05.032

[29] Chaouch, N., Ouahrani, M.R. and Laouini, S.E. (2014) Adsorption of Lead (II) from Aqueous Solutions onto Activated Carbon Prepared from Algerian Dates Stones of Phoenix Dactylifera. L (Ghars Variety) by $\mathrm{H}_{3} \mathrm{PO}_{4}$ Activation. Oriental Journal of Chemistry, 30, 1317-1322. https://doi.org/10.13005/ojc/300349

[30] Amarasinghe, B. (2011) Lead and Cadmium Removal from Aqueous Medium Using Coir Pith as Adsorbent: Batch and Fixed Bed Column Studies. Journal of Tropical Forestry and Environment, 1, 36-47.

[31] Katsoyiannis, I.A. and Zouboulis, A.I. (2002) Removal of Arsenic from Contaminated Water Sources by Sorption Onto Iron-Oxide-Coated Polymeric Materials. Water Research, 36, 5141-5155. https://doi.org/10.1016/S0043-1354(02)00236-1

[32] Fu, J., Chen, Z., Wang, M., Liu, S., Zhang, J., Zhang, J. and Xu, Q. (2015) Adsorption of Methylene Blue by a High-Efficiency Adsorbent (Polydopamine Microspheres): Kinetics, Isotherm, Thermodynamics and Mechanism Analysis. Chemical Engineering Journal, 259, 53-61. https://doi.org/10.1016/j.cej.2014.07.101

[33] Malkoc, E. and Nuhoglu, Y. (2006) Removal of Ni(II) Ions from Aqueous Solutions Using Waste of Tea Factory: Adsorption on a Fixed-Bed Column. Journal of Hazardous Materials, 135, 328-336. https://doi.org/10.1016/j.jhazmat.2005.11.070

[34] Lide, D.R. (1998). Handbook of Chemistry and Physics. CRC Press, Boca Raton.

[35] Langmuir, I. (1918) The Adsorption of Gases on Plane Surfaces of Glass, Mica and Platinum. Journal of the American Chemical society, 40, 1361-1403. https://doi.org/10.1021/ja02242a004

[36] Hull, M.S., Vikesland, P.J. and Schultz, I.R. (2013) Uptake and Retention of Metallic Nanoparticles in the Mediterranean Mussel (Mytilus Galloprovincialis). Aquatic toxicology, 140, 89-97. https://doi.org/10.1016/j.aquatox.2013.05.005

[37] Sobh, M., Moussawi, M.A., Rammal, W., Hijazi, A., Rammal, H., Reda, M. and Hamieh, T. (2014) Removal of Lead(II) Ions from Waste Water by Using Lebanese Cymbopogon Citratus (Lemon Grass) Stem as Adsorbent. American Journal of Phytomedicine and Clinical Therapeutics, 2, 1070-1080.

[38] Dalvand, A., Nabizadeh, R., Ganjali, M.R., Khoobi, M., Nazmara, S. and Mahvi, A.H. (2016) Modeling of Reactive Blue 19 Azo Dye Removal from Colored Textile Wastewater Using L-Arginine-Functionalized $\mathrm{Fe}_{3} \mathrm{O}_{4}$ Nanoparticles: Optimization, Reusability, Kinetic and Equilibrium Studies. Journal of Magnetism and Magnetic Materials, 404, 179-189. https://doi.org/10.1016/j.jmmm.2015.12.040 